\title{
Cytogenetic Analysis of HER2 in Ovarian Cancer Patients by Fluorescence in Situ Hybridization
}

\author{
Mohammad Alzeyadi ${ }^{*}$, Ameer A. Imarah, Sinan Q. Khayoon and Isra M. Alhamadani
}

Kufa University, Faculty of science, Iraq

\section{ARTICLE INFO}

Keywords:
Ovarian
HER2
FISH
TMA

\section{Introduction}

Ovarian cancer is one of the most widespread fatal full cancer of the female. Recently, it is in the fourth level of the cancer that most common and lead to cancer death in the United Kingdom female, while the breast, lung, and colorectal cancer is occupied the first three level (Jemal et al, 2007). There are new states Approximately 21,550 and 14,600 cases of deaths from ovarian cancer in the U.S in 2009 (Ohsaki et al., 2000). There are a huge numbers of histological subtypes of the complex histological classification to the cancer of ovary, with. According to WHO, types of ovarian cancers in women age 20 are as follows: 1-Surface epithelial-stromal tumour, also known as ovarian epithelial carcinoma, is the most common type of ovarian cancer. It includes serous tumour, endometriosis tumour and mucinous cystadenocarcinoma. 2Sex cord-stromal tumour, including estrogen-producing granulosa cell tumor and virilizing Sertoli-Leydig cell tumour or arrhenoblastoma, accounts for $8 \%$ of ovarian cancers. 3 -Germ cell tumor accounts for approximately $30 \%$ of ovarian tumors but only $5 \%$ of ovarian cancers. 4- Mixed tumours, include elements of more than one of the over classes of tumour histology. During the last years, several new agents targeting specific and critical pathways for ovarian cancer (Olayioye , 2001). One of these agents HER2/neu (also known as ErbB-2, ERBB2) stands for "Human Epidermal growth factor Receptor 2" and is a protein giving higher aggressiveness in ovarian cancer(Santin et al,2008).HER2-neu is member of the erbB gene

* Corresponding Author E-Mail Address: mohammed.mhawish@uokufa.edu.iq 
family and encode for transmembrane receptor-type tyrosine-protein kinases (Olayioye, 2001). It is normally involved in the signal transduction pathways leading to cell growth and differentiation in ovarian cancer (Santin et al, 2008, Coussens, 1985). Overexpression of HER$2 / \mathrm{neu}$, is seen in approximately $5 \%$ to $20 \%$ of ovarian cancers. HER 2 can be determined by several methods. The most commonly used methods are Fluorescence in situ hybridization (Wolff et al,2007), which detects gene amplification by measuring the number of copies of the HER2 gene in the nuclei of tumor cells (Sliwkowski et al,2004) HER2 amplification and overexpression are established through several molecular-biological and biochemical techniques - Southern blotting, Western blotting, PCR, ELISA. The immunohistochemical (IHC) examination of HER2 receptor protein is another commonly used method for HER2 status detection (Rubin et al,1993), and it is measuring the number of HER2 receptors on the cell surface and therefore detects receptor overexpression (Sliwkowski et al,2004).

\section{Materials and Methods}

All samples of the tumor in this study have been obtained from morphologically representative paraffin-embedded tumor tissues of ovarian carcinomas fixed in paraffin blocks were examined. The database of patients' data including the year of disease diagnosis, passport data, histological diagnosis, disease stage, number of each sample and clinical course information were create. In period 2010-2016 WHO classified a grouping of tumor samples and their histology followed. We investigated HER 2 in 303 women with ovarian cancer 192 were malignancies tumors (179 epithelial and 13 non epithelial ),18 low malignant ovarian tumors( just epithelial ), 93 - Benign ovarian tumors(77 epithelial and 16 non epithelial The method of Fluorescence In Situ Hybridization (FISH) applied on adequately prepared ovarian tumor tissue microchips (tissue microarrays, TMA) was used for HER2 gene examination by specific probes proved itself as the most commonly used and valuable analysis for routine HER2 status detection(Hauptmann et al, 2002).

\section{Results}

\section{HER2 oncogene}

All of 303 ovarian carcinomas that had been examine, the number of successfully hybridized is $303(50.2 \%), 192$ of them are malignancies tumors (179 epithelial and 13 of them are not epithelial ), 18 low malignant ovarian tumors( only epithelial ), 93 of them are benign ovarian tumors (77 epithelial and 16 non epithelial ). The availability of unsuccessfully hybridized tumors is due to various reasons: 1) loss of material; 2) an insufficient number of cells; 3) a lack of signal after hybridization; 4) irrelevant specimen acquisition from the donor block during tissue microchip preparation. We have been found that HER2 amplification in malignancies tumors just $20(10.41 \%), 19(10.61 \%)$ epithelial and in only one $(7.69 \%)$ non epithelial) (Table 1). Not found amplification in tumors with low malignant potential and benign ovarian tumors. While we established that HER2 increase in malignancies tumors, low malignant ovarian tumors as shown in (Table 2.) and just 19 Benign ovarian tumors, malignancies 14 approximately (7.29\%), low malignant only $2(11.11 \%)$ and in Benign ovarian tumors 3 $(3.22 \%)$ as shown in table 3 .

Table 1.

Frequency of HER2 copy number in ovarian carcinomas with different histological type in malignant tumours

\begin{tabular}{lccccc}
\hline \multicolumn{2}{c}{$\begin{array}{c}\text { HistologicalType Malignant } \\
\text { Tumors }\end{array}$} & $\begin{array}{c}\text { Normal } \\
\text { of HER2 signals }\end{array}$ & $\begin{array}{c}\text { HER2 } \\
\text { genetic gain }\end{array}$ & $\begin{array}{c}\text { HER2 } \\
\text { amplification }\end{array}$ & Total \\
\hline Epithelial & $\mathrm{N}$ & 149 & 11 & 19 & 179 \\
Serous & $\%$ & 83.24 & 6.14 & 10.61 & 179 \\
\hline
\end{tabular}




\begin{tabular}{|c|c|c|c|c|c|}
\hline & $\%$ & 83.72 & 5.81 & 10.46 & \multirow{3}{*}{16} \\
\hline \multirow{2}{*}{ Mucinous } & $\mathrm{N}$ & 14 & 1 & 1 & \\
\hline & $\%$ & 87.5 & 6.25 & 6.25 & \\
\hline \multirow{2}{*}{ Endometrioid } & $\mathrm{N}$ & 9 & 1 & 2 & \multirow{2}{*}{12} \\
\hline & $\%$ & 75 & 8.33 & 16.66 & \\
\hline \multirow{2}{*}{ Clear cell } & $\mathrm{N}$ & 5 & 0 & 2 & \multirow{2}{*}{7} \\
\hline & $\%$ & 71.42 & & 28.57 & \\
\hline \multirow{2}{*}{ Brenner tumors } & $\mathrm{N}$ & 1 & 0 & 0 & \multirow{2}{*}{1} \\
\hline & $\begin{array}{l}\% \\
\mathrm{~N}\end{array}$ & $\begin{array}{c}100 \\
13\end{array}$ & 2 & 2 & \\
\hline Combined & $\%$ & 76.47 & 11.76 & 11.76 & 17 \\
\hline \multirow{2}{*}{ Undifferentiated tumors } & $\mathrm{N}$ & 14 & 2 & 2 & \multirow{2}{*}{18} \\
\hline & $\%$ & 77.77 & 11.11 & 11.11 & \\
\hline \multirow{2}{*}{ Unclassification } & $\mathrm{N}$ & 21 & 0 & 1 & \multirow{2}{*}{22} \\
\hline & $\%$ & 95.45 & & 4.55 & \\
\hline \multirow{2}{*}{ Non epithelial } & $\mathrm{N}$ & 9 & 3 & 1 & \multirow{2}{*}{13} \\
\hline & $\%$ & 69.23 & 23.07 & 7.69 & \\
\hline \multirow{2}{*}{ Sex-cord stromal tumours } & $\mathrm{N}$ & 3 & 0 & 1 & \multirow{2}{*}{4} \\
\hline & $\%$ & 75 & & 25 & \\
\hline \multirow{2}{*}{ Granulosa cell tumours } & $\mathrm{N}$ & 2 & 0 & 0 & \multirow{2}{*}{2} \\
\hline & $\%$ & 100.0 & & & \\
\hline Embryonic carcinoma & $\mathrm{N}$ & 4 & $\begin{array}{c}3 \\
4285\end{array}$ & 0 & 7 \\
\hline \multirow{2}{*}{ Total } & $\begin{array}{l}\% \\
\mathrm{~N}\end{array}$ & $\begin{array}{c}57.14 \\
158\end{array}$ & $\begin{array}{c}4.85 \\
14\end{array}$ & 20 & \multirow{2}{*}{192} \\
\hline & $\%$ & 82.29 & 7.29 & 10.41 & \\
\hline
\end{tabular}

Table 2.

Frequency of HER2 copy number in ovarian carcinomas with different Histological Type in Low Malignant Tumours

\begin{tabular}{|c|c|c|c|c|}
\hline Low Malignant Tumours & & $\begin{array}{c}\text { Normal of } \\
\text { HER2 signals }\end{array}$ & $\begin{array}{c}\text { HER2 } \\
\text { genetic gain }\end{array}$ & Total \\
\hline Epithelial & $\begin{array}{l}\mathrm{N} \\
\%\end{array}$ & $\begin{array}{c}16 \\
88.88\end{array}$ & $\begin{array}{c}2 \\
11.11\end{array}$ & 18 \\
\hline Serous & $\begin{array}{l}\mathrm{N} \\
\%\end{array}$ & $\begin{array}{c}8 \\
100.0\end{array}$ & 0 & 8 \\
\hline Mucinous & $\begin{array}{l}\mathrm{N} \\
\%\end{array}$ & $\begin{array}{c}5 \\
71.42\end{array}$ & $\begin{array}{c}2 \\
28.57\end{array}$ & 7 \\
\hline Endometriosis & $\begin{array}{l}\mathrm{N} \\
\%\end{array}$ & $\begin{array}{c}1 \\
100.0\end{array}$ & 0 & 1 \\
\hline Clear cell & $\begin{array}{l}\mathrm{N} \\
\%\end{array}$ & 0 & 0 & 0 \\
\hline Brenner tumours & $\begin{array}{l}\mathrm{N} \\
\%\end{array}$ & 0 & 0 & 0 \\
\hline Combined & $\begin{array}{l}\mathrm{N} \\
\%\end{array}$ & $\begin{array}{c}2 \\
100.0\end{array}$ & 0 & 2 \\
\hline $\begin{array}{l}\text { Undifferentiated } \\
\text { tumours }\end{array}$ & $\begin{array}{l}\mathrm{N} \\
\%\end{array}$ & 0 & 0 & 0 \\
\hline Classification & $\begin{array}{l}\mathrm{N} \\
\%\end{array}$ & 0 & 0 & 0 \\
\hline Non epithelial & $\begin{array}{l}\mathrm{N} \\
\%\end{array}$ & 0 & 0 & 0 \\
\hline $\begin{array}{l}\text { Sex-cord stromal } \\
\text { tumours }\end{array}$ & $\begin{array}{l}\mathrm{N} \\
\%\end{array}$ & 0 & 0 & 0 \\
\hline Granulosa cell tumours & $\begin{array}{l}\mathrm{N} \\
\%\end{array}$ & 0 & 0 & 0 \\
\hline $\begin{array}{l}\text { Embryonal } \\
\text { carcinoma }\end{array}$ & $\begin{array}{l}\mathrm{N} \\
\%\end{array}$ & 0 & 0 & 0 \\
\hline Total & $\begin{array}{l}\mathrm{N} \\
\%\end{array}$ & $\begin{array}{c}16 \\
88.88\end{array}$ & $\begin{array}{c}2 \\
11.11\end{array}$ & 18 \\
\hline
\end{tabular}


Table 3.

Frequency of HER2 copy number in ovarian carcinomas with different histological type in benign tumours

\begin{tabular}{|c|c|c|c|c|}
\hline Benign Tumors & & $\begin{array}{c}\text { Normal of HER2 } \\
\text { signals }\end{array}$ & $\begin{array}{c}\text { HER2 } \\
\text { genetic gain }\end{array}$ & Total \\
\hline \multirow[t]{2}{*}{ Epithelial } & $\mathrm{N}$ & 74 & 3 & 77 \\
\hline & $\%$ & 96.10 & 3.81 & \\
\hline \multirow[t]{2}{*}{ Serous } & $\mathrm{N}$ & 36 & 3 & 39 \\
\hline & $\%$ & 92.3 & 7.69 & \\
\hline \multirow[t]{2}{*}{ Mucinous } & $\mathrm{N}$ & 12 & 0 & 12 \\
\hline & $\%$ & 100.0 & & \\
\hline \multirow[t]{2}{*}{ Endometrioid } & $\mathrm{N}$ & 19 & 0 & 19 \\
\hline & $\%$ & 100.0 & & \\
\hline \multirow[t]{2}{*}{ Clear cell } & $\mathrm{N}$ & 0 & 0 & 0 \\
\hline & $\%$ & & & \\
\hline \multirow[t]{2}{*}{ Brenner tumors } & $\mathrm{N}$ & 2 & 0 & 2 \\
\hline & $\%$ & 100.0 & & \\
\hline \multirow[t]{2}{*}{ Combined } & $\mathrm{N}$ & 5 & 0 & 5 \\
\hline & $\%$ & 100.0 & & \\
\hline \multirow{2}{*}{$\begin{array}{l}\text { Undifferentiated } \\
\text { tumors }\end{array}$} & $\mathrm{N}$ & 0 & 0 & 0 \\
\hline & $\%$ & & & \\
\hline \multirow[t]{2}{*}{ Unclassification } & $\mathrm{N}$ & 0 & 0 & 0 \\
\hline & $\%$ & & & \\
\hline \multirow[t]{2}{*}{ Non epithelial } & $\mathrm{N}$ & 16 & 0 & 16 \\
\hline & $\%$ & 100.0 & & \\
\hline \multirow{2}{*}{$\begin{array}{l}\text { Sex-cord stromal } \\
\text { tumours }\end{array}$} & $\mathrm{N}$ & 2 & 0 & 2 \\
\hline & $\%$ & 100.0 & & \\
\hline \multirow{2}{*}{$\begin{array}{l}\text { Granulosa cell } \\
\text { tumours }\end{array}$} & $\mathrm{N}$ & 2 & 0 & 2 \\
\hline & $\%$ & 100.0 & & \\
\hline \multirow{2}{*}{$\begin{array}{l}\text { Embryonal } \\
\text { carcinoma }\end{array}$} & $\mathrm{N}$ & 12 & 0 & 12 \\
\hline & $\%$ & 100.0 & & \\
\hline \multirow[t]{2}{*}{ Total } & $\mathrm{N}$ & 90 & 3 & 93 \\
\hline & $\%$ & 96.77 & 3.22 & \\
\hline
\end{tabular}

\section{Discussion}

Up to now, the most studies on frequency of HER2 alterations in ovarian tumors examined gene overexpression in a few numbers of tumors (Meden et al,1997, Khalifa et al, 1997). Various CGH examinations have found an additional gene material in 17q Kraggerud et al, 2000 The analysis of deferent type of ovarian. Carcinoma has shown on frequency of HER2 alterations in deferent chromosomes and deferent frequency of chromosome areas (Watanabe et al,2001). HER2 amplification and overexpression are established through several molecular-biological and biochemical techniques. (Kraggerud et al., 2000, Watanabe et al., 2001)

Our current project has used the FISH method for assessing the alterations in HER2 copy number. The highly informative technology of tissue microarray has enabled the simultaneous analysis of a great number of ovarian tumors. Thus, FISH method used on TMA with specific probe for the examined HER2 oncogene, has realized amplification and genetic gain frequency detection, thus enabling evaluation of the input of this oncogene rearrangements for the ovarian tumor occurrence and progression. In all tumors with gene amplification HER2 protein has been over expressed, implicating gene amplification as one mechanism for overexpression according to the results of Reinmuth et al (Resta et al, 1993) using double-differential polymerase chain reaction technology. Furthermore, the correlation between increasing levels of HER2 protein expression and increased gene copy number suggests that the additive effect of gene copies is an important mechanism for HER2 protein expression (Hirsch et al, 2002). Studies of HER2 gene amplification in other tumours have reported lower incidences of gene amplification 
relative to receptor overexpression, implying that in most tumours gene amplification is not the prevailing mechanism of HER2 overexpression, and that it is also unlikely to be of diagnostic value for most solid tumours (Rolitsky et al, 1999). The underlying mechanisms of HER2 protein.

Over expression are inapprehensible completely. Gene amplification was suggest as a possible mechanism for many years, but last studies pointed that other mechanisms may play a important role such as post-translational change or the length of polymorphisms in intron 1 of the EGFR gene (Kersting et al.,2004).

Aberrant HER2 copy numbers (gains and amplifications) were found in $17.70 \%$ of malignant ovarian tumors (epithelial and non-epithelial). Using the same method, Rolitsky et al (1999) Their evaluation of archive tumor material by FISH, however, has been carried out in a limited number of tumors (Werness et al, 1999), mainly of endometriod type. Ross et al. nother study using FISH (1999) performed afor detecting of HER2 gene amplification. They have established even a higher frequency of HER2 amplification (66\%) in 40 of a total of 61 ovarian epithelial carcinomas. Bian et al. demonstrated amplification in 9 of 65 adenocarcinomas (14\%) Watanabe et al,2001). The reasons for the differences in various study results may (lay in the limited number of tumors analyzed as well as in differences of amplification definitions. Our collection included ovarian tumors of all histologic types and subtypes. These various histologic types of ovarian tumors have demonstrated difference in HER2 gain and amplification frequencies. We established HER2 amplification associated with light cell carcinomas. This is in consent with Rolitsky et al., who have found that amplification is associated with serous subtypes $(\mathrm{p}=0.002)$, while HER2 protein overexpression - with only light cellular subtype Rolitsky et (al,1999 Our results suggest that alterations in HER2 copy number are particularly). characteristic for the light cell ovarian tumors. Our suggestion is supported by the immunohistochemical (IHC) examinations of Fujimura et al., who have established the highest HER2 protein overexpression in light cellular (42.9\%) subtype (Ross et al,1999). Our study has not found amplification in tumors with low malignant potential. This is in consent with Ross et al (1999), who reported that HER2 amplification is of exceptional occurrence in low malignant ovarian tumors compared to malignant ones Kraggerud et al, 2000 ().Another study has found significantly decreased expression of HER2 protein in low malignant potential tumors compared to carcinomas Rolitsky et al,1999 The authors ().have suggested that the number of HER2 positive adenocarcinomas increases with disease progression.

Benign ovarian tumors show almost a lack of genetic gain (except for the serous subtype) and amplification, which means that HER2 alterations are not an early phenomenon in ovarian tumorogenesis (Kraggerud et al,2000).This is supported by the study of Werness et al., suggesting that increased HER2 expression occurs later in invasive tumor development and has its role in the late pathogenesis of ovarian carcinoma (Ross et al,1999). Finally, the great number of ovarian tumors analyzed by FISH on TMA enabled us to assess the frequency of HER2 gene alterations, the gene being of great importance to cancerogenesis, and to examine it in the contest of various tumor phenotypes.

In conclusion conceder the detecting and simultaneous quantification of HER2 overexpression gene by means of FISH assay, might enable the showing of a more precise stratification of ovarian cancer patients by equipping additional prognostic identification and diagnostic information. This explorative might be providing the specific therapeutic targeting with respect to individualised therapy.

\section{References}

Al-Zeyade, M. (2008). Tissue Microarray Analysis of EGFR Copy Number Changes In Lung Cancer. Msc. degree. Sofia University-Faculty of biology. 
Coussens L., (1985). Tyrosine Kinase Receptor with Extensive Homology to EGF Receptor Shares Chromosomal Location with neu Oncogene. Science 230: 1132-1139

Hauptmann, S., Denkert, C., Koch, I., Petersen, S., Schluns, K., Reles, A., Dietel, M., Petersen, I. (2002). Genetic alterations in epithelial ovarian tumors analyzed by comparative genomic hybridization. Hum Pathol (Jun); 33(6): 632-641.

Hirsch, F.R., Varella-Garcia, M., Franklin, W.A., et al (2002). Evaluation of HER2/neu in non-small cell lung cancer by immunohistochemistry and fluorescence in-situ hybridization (FISH) techniques. Br J Cancer 86:1449-1456, [Medline]

Jemal, A.; Thomas, A.; Murray, T. and Thun, M., (2007), Cancer statistics. cancer J Clin;57;4366.

Kersting C, Tidow N, Schmidt H, et al. (2004). Gene dosage PCR and fluorescence in situ hybridization reveal low frequency of egfr amplifications despite protein overexpression in invasive breast carcinoma. Lab Invest; 84:582-7. [CrossRef][Medline]

Khalifa,-M-A; Lacher,-D-A; Lage,-J-M; Mannel,-R-S; Walker,-J-L; Angros,-L-H; Min,-K-W. (1997). Immunohistochemical assessment of proliferation markers and altered gene expression in archival specimens of ovarian epithelial tumors. Cancer-Detect-Prev.; 21(6): 532-539.

Kraggerud,-S-M; Szymanska,-J; Abeler,-V-M; Kaern,-J; Eknaes,-M; Heim,-S; Teixeira,-M-R; Trope,-C-G; Peltomaki,-P; Lothe,-R-A. (2000). DNA copy number changes in malignant ovarian germ cell tumors. Cancer-Res. Jun 1; 60(11): 3025-3030.

Massion PP.; Taflan PM.; Jamshedur Rahman SM. et al, (2003), "Significance of p63 amplification and overexpression in lung cancer development and prognosis" Cancer Res; 63: 7113-7121 Medline 14612504.

Meden H., Marx D., Roeglen T. et al (1998). Overexpression of the oncogene c-erbB-2 (HER2/neu) and response to chemotherapy in patients with ovarian cancer. Int J Gynecol Pathol; 17: 61-65.

Meden H.; Kuhn W., (1997). Overexpression of the oncogene c-erbB-2 (HER2/neu) in ovarian cancer: A new prognostic factor. Eur J Obstet Gynecol Reprod Biol (Feb); 71: 173-179.

Ohsaki, Y. et al., (2000). Epidermal growth factor receptor expression correlates with poor prognosis in non-small cell lung cancer patients with p53 overexpression. Oncol. Rep. 7, 603-607.

Olayioye MA (2001). Update on HER-2 as a target for cancer therapy: intracellular signaling pathways of ErbB2/HER-2 and family members. Breast Cancer Res 3 (6): 385-389.

Resta L., Russo S., Colucci G. (1993). Morphologic precursors of ovarian epithelial tumors. Obstet Gynecol; 82: 181-186.

Rolitsky, -C-D; Theil,-K-S; McGaughy,-V-R; Copeland,-L-J; Niemann,-T-H. (1999). HER2/neu amplification and overexpression in endometrial carcinoma. Int-J-Gynecol-Pathol.; 18(2): 138-143.

Ross J.S., Yang F., Kallakur B.V.S., Sheehan C.E., Ambros R.A., Muraca P.J. (1999). HER2/neu Oncogene Amplification by Fluorescence In Situ Hibridization in Epithelial Tumors of the Ovary. Anatomic Pathology/ HER-2/neu Gene Amplification in Ovarian Epithelial Tumors. Am J Clin Pathol; 111: 311-316 
Rubin S.C., Finstad C.L., Wong G.Y. et al (1993). Prognostic significance of HER-2/neu expression in advanced epithelial ovarian cancer: A multivariate analysis. Am J Obstet Gynecol; 168: 162-169.

Santin AD.; Bellone S.; Roman JJ.; McKenney JK.; Pecorelli S., (2008). Trastuzumab treatment in patients with advanced or recurrent endometrial carcinoma overexpressing HER2/neu. Int J Gynaecol Obstet 102 (2): 128-31.

Sliwkowski MX.; Harris JR.; Lippman ME.; Morrow M.; Osborne CK, eds. (2004). Diseases of the Breast. 3rd ed. Philadelphia, PA: Lippincott Williams \& Wilkins: 415-426

Watanabe, -T; Imoto,-I; Kosugi,-Y; Ishiwata,-I; Inoue,-S; Takayama,-M; Sato,-A; Inazawa,-J. A (2001). novel amplification at 17q21-23 in ovarian cancer cell lines detected by comparative genomic hybridization. Gynecol-Oncol. May; 81(2): 172-177.

Werness,-B-A; Afify,-A-M; Eltabbakh,-G-H; Huelsman,-K; Piver,-M-S; Paterson,-J-M. (1999), p53, c-erbB, and Ki-67 expression in ovaries removed prophylactically from women with a family history of ovarian cancer. Int-J-Gynecol-Pathol.; 18(4):338-343. 